\title{
FACTORS AFFECTING THE SATISFACTION LEVEL OF MEDICAL TOURISTS: A CASE STUDY OF DELHI NATIONAL CAPITAL REGION
}

\author{
Bivek DATTA* \\ Amity University Uttar Pradesh, Amity Institute of Travel and Tourism, \\ Sector-125, Noida, India, e-mail: bdatta@amity.edu
}

\begin{abstract}
Citation: Datta, B. (2020). FACTORS AFFECTING THE SATISFACTION LEVEL OF MEDICAL TOURISTS: A CASE STUDY OF DELHI NATIONAL CAPITAL REGION. GeoJournal of Tourism and Geosites, 29(2), 628-635. https://doi.org/10.30892/gtg.29219-494
\end{abstract}

\begin{abstract}
The medical tourism industry is considered to be one of the fastest growing niche forms of tourism globally. In numerical terms by 2024 it is expected to generate revenue close to 28 billion USD. According to Ministry of Tourism India's medical tourism industry could generate revenue worth 9 billion USD considering a growth of $200 \%$ by 2020 . The study was conducted on 400 medical tourists in Delhi National Capital Region to find their perception pertaining to their satisfaction on various variables of medical tourism. Factor Analysis was utilized to reduce these 12 variables into 3 factors i.e. hospital services, quality of treatment, touristic services. A multiple regression was employed to eventually identify the factors affecting the overall satisfaction level of medical tourists visiting Delhi National Capital Region. The study indicates that quality of treatment has contributed the most and has stronger effect towards the satisfaction level of medical tourists as compared to other independent variables in Delhi National Capital Region.
\end{abstract}

Key words: Medical tourists, satisfaction level, Factor Analysis, Delhi National Capital Region, Multiple Regression

\section{INTRODUCTION}

India has seen a boom in the medical tourism industry and in terms of scale it is expected to grow by $200 \%$ by 2020 according to the forecast made by Ministry of Tourism. Medical Tourism is one of the fastest growing niche forms of tourism. The top ten source markets feature from south Asia, Middle East, central Asia and Africa. To make the e-tourism visa regime more viable the government of India has expanded its horizons and touched newer scales by introducing medical visas on February, 2019. The maximum duration permitted for availing the medical visa is six months. There is a huge potential in the medical tourism sector in India. There are many lucrative offers on store in the medical tourism sector such as cost effectiveness, qualitative health care, specialized treatments, minimum waiting periods, new countries to explore and a totally new experience. India

\footnotetext{
* Corresponding author
} 
stands tall on several aspects pertaining to medical tourism. India offers cost effective medical treatment, state of the art medical technologies, strict compliance of quality standards and following the norms of NABH (National Accreditation Board for Hospitals and Healthcare Providers) and JCI (Joint Commission International), trained medical professionals, English speaking healthcare service providers. India is majorly known globally in specialized medical areas such as hip replacement surgeries, ophthalmological treatments, cardio-vascular disorders, bone marrow transplants to name a few.

\section{LITERATURE REVIEW}

\section{Advent of Medical Tourism:}

Medical tourism has always seemed to be an area of health tourism in the scholarly works pertaining to this area of study. (Reddy et al., 2010), and is a new global niche market (Hunter, 2007). Health tourism points towards the idea of a systematized travel outside one's own domicile for the preservation, augmentation or refurbishment of the individual's well-being (Carrera \& Bridges, 2006). It is witnessed that few Asian countries i.e. Thailand, Singapore, India, South Korea, and Malaysia laid impetus in promoting medical tourism which has eventually helped them to successfully attract 1.3 million medical tourists from all over the world and numerically it continues to surge (Jafari et al., 2014). In 2012, the health tourism sectors in India and Singapore earned $\$ 2$ billion and $\$ 1$ million in incomes respectively from medical tourism (Momeni et al., 2018). Medical Tourism is undertaken by people who travel outside one's own domicile country to acquire medical, dental, and surgical care while concurrently being in pursuit of leisure and recreation (Connell, 2006).

Medical tourism comprises of two major constituents: one is medical subcontracting which is travel undertaken from one's own domicile to obtain treatment in another country (Jones \& Keith, 2006). The second constituent points towards restoration and the leisure activities available at the destination (Hunter, 2007). Numerous scholarly researches point towards the upsurge of medical tourism in recent years (Hall, 2011).

\section{Growth of Medical Tourism}

Medical tourism came into existence because of high cost of treatment in one's own domicile country (Burkett, 2007; Carrera \& Bridges, 2006; Demicco \& Cetron, 2006), the deficiency of certain medical procedures (Crooks et al., 2010; Henderson, 2004; Lunt \& Carrera, 2010; Smith et al., 2011), looking for advanced qualitative medical care (Hunter, 2007; Teh, 2007), prolonged waiting queues (Connell, 2006; Gupta, 2004; Lunt \& Carrera, 2010; Jones \& Keith, 2006; Teh, 2007), lesser restrictions to travel in terms of visa facilitation (Carrera \& Bridges, 2006).

Medical tourism has seen an upsurge in recent times focusing extensively on the ever-expanding medical tourism market. The areas touched upon by the scholarly community includes the global trends, emerging markets, risks and perceptions, prospects and opportunities (Arellano, 2007; Burkett, 2007; Carrera \& Bridges, 2006; Castonguay \& Brown, 1993; Connell, 2006; Demicco \& Cetron, 2006; Goodrich, 1993; Henderson, 2004; Hunter, 2007; Jones \& Keith, 2006; Teh, 2007), decision making techniques adopted by prospective medical tourists (Bies \& Zacharia, 2007; CaballeroDanell \& Mugomba, 2007; Heung et al., 2010; Martin et al., 2011) and reviews of previous researches on medical tourism (Crooks et al., 2010; Lunt \& Carrera, 2010; Smith et al., 2011). Scholarly work also indicates towards exploring behavior of medical tourist, motivation of medical tourist in pursuit of seeking medical treatment (Ye et al., 2011), opinions of medical tourists (Reddy et al., 2010), tourists' quest for medical tourism (Yu \& Ko, 2012) and overall factors influencing medical tourism (Moghimehfar \& Nasr-Esfahani, 2011). Among health tourism sub-groups, medical tourism can be regarded as a product of the rapid growth of the health industry (Aziz et al., 2015). 


\section{Tourist Satisfaction}

Tourist satisfaction is a well-researched aspect in the scholarly literature as it is of paramount importance for the destinations and understanding the psyche of the tourists is an important aspect in evaluation of destination products and services' performance (Yoon \& Uysal, 2005). Multiple scholarly research accentuates the idea that the level of tourists' satisfaction influences both destination selection of first time visitors and the dynamics of repeat visit (Kozak \& Rimmington, 2000). Researches also indicate that the tourist's satisfaction level is closely related to their trustworthiness pertaining to the destination as apparent in their repeat movement patterns as well their endorsements to other prospective customers through word of mouth (Huh \& Uysal, 2003). In respect to satisfaction level of medical tourist's qualitative medical services are often named in the scholarly literature whereby the medical tourist finds it difficult to assess the quality of the service even after the service is consumed. Literatures also point that an ill-advised destination selection might result in below par medical service quality and a likely disastrous outcome for the medical tourist. Since the risk factor is high medical tourism is a very high-involvement product and needs thorough investigation (Bies \& Zacharia, 2007; Lamb et al., 2010).

\section{RESEARCH METHODOLOGY}

The data was collected from 400 medical tourists who Delhi NCR for seeking medical treatment. Since they are the primary customers of the healthcare facility their satisfaction level needs to be gauged by the policy framers. Descriptive and analytical statistics were used to derive inferences from the data. Both primary and secondary data were used to present meaningful explanations. A structured questionnaire was chosen to collect the primary data among the medical tourists visiting Delhi National Capital Region. The Data Analysis was carried out through the following steps:

a. Primary Data was collected from medical tourists pertaining to medical infrastructure, credibility of doctors, service orientation of medical staff, quality of medical treatment, less waiting time, low cost of treatment, seeking advanced technologies or quality care, hygienic factors in hospitals, infrastructure of the hospital, image of India as a tourist destination, quality certifications of hospitals, tourist attractions;

b. Descriptive and Analytical Statistics is employed;

c. Employing statistical tools.

\section{DATA ANALYSIS, INTERPRETATION AND RESULTS}

In order to investigate the satisfaction level of medical tourists a compilation of 12 variables were done. 400 patients were surveyed in order to understand their overall satisfaction on the various facets pertaining to medical tourism in India. The variables used for the study were derived based on secondary data. These were medical infrastructure, credibility of doctors, service orientation of medical staff, quality of medical treatment, less waiting time, low cost of treatment, seeking advanced technologies or quality care, hygienic factors in hospitals, infrastructure of the hospital, image of India as a tourist destination, quality certifications of hospitals, tourist attractions The above mentioned 12 variables were reduced to 3 factors through factor analysis. A multiple regression was also employed on these 3 factors which were considered as independent variables and overall satisfaction of the medical tourists was considered as dependent variable. This eventually helped in identifying the main factors affecting the overall satisfaction of medical tourists.

The variables with a mean value higher than 4 included medical infrastructure, less waiting time, hygienic factors in hospitals, quality certification of hospitals. Infrastructure of the hospital and service orientation of medical staff have lowest mean values. 
Table 1. Attributes pertaining to Satisfaction of Medical Tourists

\begin{tabular}{|l|c|c|}
\hline \multicolumn{1}{|c|}{ Attributes } & Mean & Standard Deviation \\
\hline Medical infrastructure & 4.51 & 0.88 \\
\hline Credibility of doctors & 3.51 & 1.03 \\
\hline Service orientation of medical staff & 3.41 & 1.04 \\
\hline Quality of medical treatment & 3.91 & 0.95 \\
\hline Less waiting time & 4.13 & 0.74 \\
\hline Low cost of treatment & 4.81 & 0.43 \\
\hline Seeking advanced technologies or quality care & 3.71 & 0.90 \\
\hline Hygienic factors in hospitals & 4.60 & 0.67 \\
\hline Infrastructure of the hospital & 3.24 & 1.06 \\
\hline Image of India as a tourist destination & 4.72 & 0.73 \\
\hline Quality certifications of hospitals & 4.01 & 1.05 \\
\hline Tourist Attractions & 3.60 & 0.80 \\
\hline
\end{tabular}

\section{FACTOR ANALYSIS}

Kaiser-Meyer-Olkin measure of sampling adequacy was done for applying factor analysis. It was equal to 0.832 (Table 2) that specified goodness of sample greater than 0.5 of acceptable limit. Bartlett's test of sphericity was applied and the data delivered a value of 0.00 which was less than 0.05 and reinforced the rationality of the data for factor analysis.

Table 2. KMO and Bartlett's Test (Responses of Medical Tourists)

\begin{tabular}{|c|c|c|}
\hline \multicolumn{3}{|c|}{ KMO and Bartlett's Test (Responses of Respondents) } \\
\hline \multicolumn{2}{|c|}{ Kaiser-Meyer-Olkin Measure of Adequacy of Sample } & 0.832 \\
\hline \multirow{3}{*}{ Bartlett's Test of Sphericity } & Chi-Square value & 309.342 \\
\cline { 2 - 3 } & Df & 10 \\
\cline { 2 - 3 } & Sig. & 0.000 \\
\hline
\end{tabular}

Table 3. Factor Analysis

\begin{tabular}{|c|c|c|c|c|c|c|c|c|c|}
\hline \multirow{2}{*}{ Component } & \multicolumn{3}{|c|}{ Initial Eigenvalues } & \multicolumn{3}{c|}{$\begin{array}{c}\text { Extraction Sums } \\
\text { of Squared Loadings }\end{array}$} & \multicolumn{3}{c|}{$\begin{array}{c}\text { Rotation Sums of } \\
\text { Squared Loadings }\end{array}$} \\
\cline { 2 - 10 } & Total & $\begin{array}{c}\text { \% of } \\
\text { Variance }\end{array}$ & $\begin{array}{c}\text { Cumulative } \\
\%\end{array}$ & Total & $\begin{array}{c}\% \text { of } \\
\text { Variance }\end{array}$ & $\begin{array}{c}\text { Cumulative } \\
\%\end{array}$ & Total & $\begin{array}{c}\% \text { of } \\
\text { Variance }\end{array}$ & $\begin{array}{c}\text { Cumulative } \\
\%\end{array}$ \\
\hline 1 & 5.400 & 45.003 & 45.003 & 5.400 & 45.003 & 45.003 & 5.090 & 42.419 & 42.419 \\
\hline 2 & 2.859 & 23.826 & 68.829 & 2.859 & 23.826 & 68.829 & 3.015 & 25.129 & 67.548 \\
\hline 3 & 1.347 & 11.226 & 80.056 & 1.347 & 11.226 & 80.056 & 1.501 & 12.508 & 80.056 \\
\hline 4 & .876 & 7.300 & 87.356 & & & & & & \\
\hline 5 & .575 & 4.793 & 92.148 & & & & & & \\
\hline 6 & .513 & 4.279 & 96.427 & & & & & & \\
\hline 7 & .237 & 1.974 & 98.401 & & & & & & \\
\hline 8 & .141 & 1.179 & 99.579 & & & & & & \\
\hline 9 & .034 & .280 & 99.859 & & & & & & \\
\hline 10 & .015 & .122 & 99.980 & & & & & & \\
\hline 11 & .002 & .020 & 100.000 & & & & & & \\
\hline 12 & $-7.818 \mathrm{E}-16$ & $-6.515 \mathrm{E}-15$ & 100.000 & & & & & & \\
\hline
\end{tabular}

Kaiser (1974) endorses that any value of 0.5 arrived through KMO and Bartlett's is acceptable and factor analysis can be applied in this case. If the value arrived is less than 0.5 then we can think of gathering more data. The values arrived between 0.5 and 0.7 are considered to be the average ones, the values arrived between 0.7 and 0.8 are considered to be rather good, and values in the range of 0.8 and 0.9 are considered to be great and values above 0.9 are excellent. In our case the value arrived is 0.832 , which is highly reliable 
and great in nature. Factor analysis is suitable and appropriate pertaining to our data.EFA was carried out on the 12 variables in order to condense the number of variables into factors. The variables are condensed into 3 factors with Eigen value greater than 1 and the total variance explicated being $80.056 \%$ and is considered to be good displayed in Table 3 .

\section{Extraction Method: Principal Component Analysis}

Variables loaded into three factors have been extracted through Varimax which is the best orthogonal rotation technique as it enhances the interpretability of the factors (Table 4). EFA was carried out for all the 12 variables. These variables are condensed into three different factors which explicated around $80.056 \%$ of the total variance. The first factor explained about $42.419 \%$ of the total variance. The second factor explained about $25.129 \%$ of the total variance and third factor explained $12.508 \%$ of the total variance. All the three factors explained about $80.056 \%$ of the total Variance.

Table 4. Rotated Component Matrix

\begin{tabular}{|l|l|l|l|}
\hline \multicolumn{3}{|c|}{ Rotated Component Matrix } \\
\hline \multirow{2}{*}{ Variables/Factors } & \multicolumn{3}{c|}{ Component } \\
\cline { 2 - 4 } & $\mathbf{1}$ & $\mathbf{2}$ & \multicolumn{1}{|c|}{$\mathbf{3}$} \\
\hline Medical infrastructure & .030 & $\mathbf{. 7 6 8}$ & .114 \\
\hline Credibility of doctors & -.031 &. $\mathbf{7 3 9}$ & .049 \\
\hline Service orientation of medical staff & $\mathbf{. 7 8 1}$ & .418 & -.141 \\
\hline Quality of medical treatment & .187 & $\mathbf{. 9 0 1}$ & .138 \\
\hline Less waiting time & $\mathbf{. 9 0 8}$ & .288 & .188 \\
\hline Low cost of treatment & $\mathbf{. 7 5 6}$ & -.423 & -.331 \\
\hline Seeking advanced technologies or quality care & .102 & $\mathbf{. 6 3 8}$ & -.621 \\
\hline Hygienic factors in hospitals & $\mathbf{. 9 3 4}$ &. .082 & .169 \\
\hline Infrastructure of the hospital & $\mathbf{. 9 6 8}$ & .042 & .177 \\
\hline Image of India as a tourist destination & .518 & .084 & $\mathbf{. 5 7 8}$ \\
\hline Quality certifications of hospitals & $\mathbf{. 9 7 1}$ & -.102 & .155 \\
\hline Tourist Attractions & .142 & .447 & $\mathbf{. 7 0 9}$ \\
\hline
\end{tabular}

Extraction Method: Principal Component Analysis

Rotation Method: Varimax with Kaiser Normalization.

a. Rotation converged in 5 iterations.

Table 5. Identification of New Parameters by factor analysis

\begin{tabular}{|c|c|c|c|c|c|c|}
\hline Factors & \multicolumn{5}{|c|}{ Variables } & New Parameters \\
\hline F 1 & Variable 3 & Variable 5 & Variable 6 & Variable 8 & Variable 9 and 11 & Hospital services \\
\hline F 2 & Variable 1 & Variable 2 & Variable 4 & Variable 7 & & Quality of treatment \\
\hline F 3 & Variable 10 & Variable 12 & & & & Touristic services \\
\hline
\end{tabular}

All the 12 variables are condensed into 3 factors. The extraction of the factors was carried out through the Varimax method and through principal component analysis where the Eigen value should be more than 1 . Variables 3, 5, 6, 8, 9 \& 11 forms factor 1 which is named as Hospital services. 1, 2, 4 and 7 variable constitute factor 2 which is named as Quality of treatment. Variable 10 and 12 establishes factor 3 and is named as Touristic services shown by Table 5 .

\section{Regression Analysis:}

The theories and ideologies developed in dealing with sample linear regression (i.e. one explanatory variable) may be protracted to deal with numerous explanatory variables.

\section{Multiple Regression equation:}

$\mathrm{Y}=\mathrm{C}+\beta \mathrm{x} 1+\beta \mathrm{x} 2+\beta \mathrm{x} 3+\beta \mathrm{x} 4+\beta \mathrm{x} 5+\ldots .+\beta \mathrm{xn}$

$\mathrm{Y}=$ prediction relationship of types of variables towards Service Quality;

$\mathrm{C}=$ Constant value; 
$\beta=$ Unstandardized Coefficient;

$\mathrm{X} 1, \mathrm{X} 2 . . .$. = Dimension of independent variable (Source: Algina \& Olejnik, 2003).

The Regression Analysis predicts the extent of dependence of various factors as its exploratory variable. This was carried out by statistical testing and utilizing the first result of the regression analysis i.e. ANOVA (F-test). Further, R square value of the regression analysis is calculated to demonstrate the degree to which the explanatory variables explain the dependent factor. The regression analysis further elaborates the result i.e. $t$-test along with significant value ( $p$-value) indicates the most significant explanatory variable that influences the dependent variable. The $\mathrm{R}$ square value of the multiple regression model is deduced as 0.987 , which shows that the dependent variable i.e. Responses of Medical Tourists is influenced by all these three variables i.e. i.e. 98.7 percent which is a good indicator for establishing satisfaction level (Table 6).

Table 6. Multiple Regression Summary Output (Responses of Medical Tourists)

\begin{tabular}{|l|l|}
\hline \multicolumn{2}{|c|}{ Multiple Regression Summary Output (Responses of Medical Tourists) } \\
\hline Regression Statistics & 0.989 \\
\hline Multiple R & 0.987 \\
\hline R Square & 0.984 \\
\hline Adjusted R Square & 0.020 \\
\hline Standard Error & 400 \\
\hline Observations &
\end{tabular}

Table 7. Multiple Regression (ANOVA) (Data source: Developed from the research)

\begin{tabular}{|l|l|l|l|l|l|l|}
\hline \multicolumn{2}{|c|}{ Model } & $\begin{array}{l}\text { Sum of } \\
\text { Squares }\end{array}$ & Df & $\begin{array}{l}\text { Mean } \\
\text { Square }\end{array}$ & F & Sig. \\
\hline \multirow{3}{*}{1} & Regression & 84.614 & 3 & 28.205 & 4604.336 &. .00 $^{*}$ \\
\cline { 2 - 8 } & Residual & 2.426 & 396 & .006 & & \\
\cline { 2 - 8 } & Total & $\mathbf{8 7 . 0 4 0}$ & $\mathbf{3 9 9}$ & & & \\
\hline
\end{tabular}

*Significant at 1 per cent level

Table 8. Multiple Regression Coefficients (Responses of Medical Tourists)

\begin{tabular}{|l|l|l|l|l|}
\hline \multicolumn{1}{|c|}{ Factors } & Coefficients & Standard Error & \multicolumn{1}{c|}{ t Stat } & \multicolumn{1}{c|}{ P-value } \\
\hline Intercept & -0.002 & 0.002 & -0.998 & 0.321 \\
\hline F1 & 0.194 & 0.002 & 100.327 & $0.000^{*}$ \\
\hline F2 & 0.213 & 0.012 & 100.809 & $0.000^{*}$ \\
\hline F3 & 0.199 & 0.132 & 100.574 & $0.000^{*}$ \\
\hline
\end{tabular}

Table 9. Factors and New Parameters

\begin{tabular}{|l|l|}
\hline Factors & New Parameters \\
\hline${ }^{*} \mathbf{F} 1$ & Hospital services \\
\hline${ }^{*} \mathbf{F} 2$ & Quality of treatment \\
\hline${ }^{*} \mathbf{F} 3$ & Touristic services \\
\hline${ }^{*}$ Significant at 1 per cent level
\end{tabular}

The ANOVA (F-test) indicates that the scale/ factor i.e. "Responses of Medical Tourists" was quite significant. All the explanatory variables i.e. three factors for studying responses of Medical Tourists regarding overall satisfaction level are quite significant. Further, table 8 depicts that the significant value (p-value) of F-test came out to be o.ooo, which means that all three explanatory variables which are Hospital services, Quality of treatment, Touristic services are highly significant with respect to the explained factor i.e. "Responses of Medical tourists". The above Table 7 determines acceptable result as the significance level of the model is less than 0.01 (1\% level). Thus the model employed in this 
research is considered to be good. The application of multiple regression on the responses of medical tourists and its constituent variable we can develop the below mentioned equation.

Responses of Medical Tourists $(Y)=-.002+0.194(F 1)+0.213(F 2)+0.199(F 3)$

It can be further deduced that the rise of 1 unit of delivery of Factor 1(F1), may result in the rise of 0.194 units in Responses of Medical Tourists (Y). The highest Beta value specifies that independent variables are the most significant variables towards the dependent variable. From the table 8 depicted above, the independent factor 2 of 0.213 is highest amongst all the three factors. This means that independent Factor 2 i.e. quality of treatment has contributed the most and has stronger effect towards the satisfaction level as compared to other independent variables. Further, it is witnessed from Table 8 that the significant value (p-value) of t-test for all items are o.ooo, which shows that all the three condensed factors arrived through factor analysis are highly significant with respect to the dependent variables i.e. "Responses of Medical Tourists" (Table 9). The application of the ANOVA (F-test) indicates that the scale/ factor i.e. "Responses of Medical Tourists" regarding satisfaction level was quite significant. All the explanatory variables i.e. three factors for studying responses of Medical Tourists are quite significant i.e. Hospital services, Quality of treatment, Touristic services. Further statistical Analysis displays that the significant value (p-value) of F-test came out to be 0.000 , which means that all three variables are highly significant with respect to the responses of medical tourists regarding satisfaction level”.

\section{DISCUSSIONS AND FUTURE IMPLICATIONS}

Though this study is a modest and earnest effort from the researcher to investigate the satisfaction level of medical tourists in Delhi NCR and it is a herculean task to study all the aspects of this emerging segment due to limited resources and abilities of the researcher and confidentiality issues of the hospitals. Hence the study may not be comprehensive to all situations. The study was conducted with a view to provide an allinclusive view of the satisfaction level of Medical tourists. It also provided few insights on how the stakeholders of the medical tourism industry can address the concerns of medical tourists pertaining to their satisfaction level. The hospitals need to understand the expectations and satisfaction of medical tourists on various parameters and thereby focus on improving their facilities and services to cater to the needs of the medical tourists.

\section{LIMITATIONS OF THE STUDY}

1. The study is conducted in Delhi National Capital Region. There are other principal medical tourism centres such as Hyderabad, Bengaluru, Mumbai, and Kolkata. The findings of the study may not be generalized to these areas.

2. Hospitals are reluctant and hesitant to reveal information pertaining to medical tourists from their data base.

3. No prior major research work has been conducted in this area.

4. The study was highly time consuming and incurred financial constraints.

\section{REFERENCES}

Algina, J. \& Olejnik, S. (2003). Sample size tables for correlation analysis with applications in partial correlation and multiple regression analysis. Multivariate Behavioural Research, 38(3), 309-323.

Arellano, A.B.R. (2007). Patients without borders: the emergence of medical tourism. International Journal of Health Service, 37(1), 193-198.

Aziz, A., Yusof. R.M., Ayob, M., Bakar N.T.A. \& Awang, A.H. (2015) Measuring tourist behavioural intention through quality in Malaysian medical tourism industry. Proc Econ Finance, 31:280-5. doi: 10.1016/s22125671(15)01179-x. 
Bies, W. \& Zacharia, L. (2007). Medical tourism: Outsourcing surgery. Mathematical and Computer Modelling, 46, $1144-1159$. Brown, S.T. \& Swartz, T. A. (1989). A gap analysis of professional service quality. The Journal of Marketing, 53(2), 92-98. Burkett, L. (2007). Medical tourism concerns, benefits and the American legal perspective. The Journal of Legal Medicine, 28(2), 1-20.

Caballero-Danell, S. \& Mugomba, C. (2007). Medical tourism and its entrepreneurial opportunities- $A$ conceptual framework for entry into the industry (Master's thesis). Gothenburg University, Sweden.

Carrera, P.W. \& Bridges, J.F.P. (2006). Globalization and healthcare: understanding health and medical tourism. Expert Review of Pharmaco economics \& Outcomes, 6, 447-454.

Castonguay, G. \& Brown, A. (1993). Plastic surgery tourism providing a boon for Costa Rica's Surgeons. Canadian Medical Association Journal, 148(1), 74-76.

Chang, D.Y. (2009). Service quality assessment of a chain steakhouse in Taiwan. Journal of Quality Assurance in Hospitality \& Tourism, 10(4), 255-278.

Connell, J. (2006). Medical tourism: Sea, sun, sand and ... surgery. Tourism Management, 27, $1093-1100$.

Cronin Jr, J. \& Taylor, S. (1992). Measuring service quality: a re-examination and extension. The Journal of Marketing, 56(3), 55-68.

Crooks, V.A., Kingsbury, P., Snyder, J. \& Johnston, R. (2010). What is known about the patient's experience of medical tourism? A scoping review. BMC Health Services Research, 10(266), 1-12.

Demicco, F J. \& Cetron, M. (2006). Club Medic. Asia Pacific Biotech News, 10(10), 527-531.

G. A. \& Keith, L. G. (2006). Medical tourism and reproductive outsourcing; the dawning of a new paradigm for healthcare. International Journal of Fertility, 51(6), 251-255.

Goodrich, J.N. (1993). Socialist Cuba: A case of health tourism. Journal of Travel Research, Summer, 36-41.

Gupta, A.S. (2004). Medical tourism and public health. People's Democracy, 28(19). Retrieved March 7, 2008 from http://pd.cpim.org/2004/0509/05092004_snd.htm.

Hall, C.M. (2011). Health and medical tourism: a kill or cure for global public health? Tourism Review, 66(1/2):4-15

Henderson, J.C. (2004). Healthcare tourism in Southeast Asia. Tourism review International, 7(3-4), $111-121$.

Heung, V.C.S., Kucukusta, D. \& Song, H. (2010). A conceptual model of medical tourism: implications for future research. Journal of Travel \& Tourism Marketing, 27(3), 236-251.

Huh, J\& Uysal, M. (2003). Satisfaction with cultural/heritage sites: Virginia historic Triangle. Journal of Quality of Assurance in Hospitality \& Tourism, 4(3-4), 1-77194.

Hunter, W. C. (2007). Medical tourism: a new global niche. International Journal of Tourism Sciences, 7(1), 129-140.

Hunter-Jones, P. (2005). Cancer and tourism. Annals of Tourism Research, 32(1), 70-92.

Jafari, M., Sadeghifar, J., Raadabadi, M., Mosavi, SM., Khodayari Zarnaq, R. \& Bahadori, M. (2014) The inquiry of international standards for medical tourism: A case study into hospitals of Tehran University of Medical Sciences. IntJTravelMedGlobalHealth, 2(2):45-50.

Jones, G.A. \& Keith, L.G. (2006). Medical tourism and reproductive outsourcing; the dawning of a new paradigm for healthcare. International Journal of Fertility, 51(6), 251-255.

Kaiser, H. (1974). An index of factor simplicity. Psychometrika, 39: 31-36

Kozak, M, \& Rimmington, M. (2000). Tourist satisfaction with Mallorca, Spain, as an off-season holiday destination. Journal of travel research, 38, 260-269.

Lamb, C.W., Hair, J.F. \& McDaniel, C. (2010). MKTG 4. Mason, OH: South-Western College Publishing.

Lunt, N. \& Carrera, R. (2010). Medical tourism: assessing the evidence on treatment abroad. Maturitas, 66(1), $27-32$.

Martin, D.S., Ramamonjiarivelo, Z. \& Martin, W.S. (2011). Medtour: A scales for measuring medical tourism intentions. Tourism Review, 66(1/2), 45-56.

Moghimehfar, F. \& Nasr-Esfahani, M. H. (2011). Decisive factors in medical tourism destination choice: A case study of Isfahan, Iran and Fertility treatment. Tourism Management, 32, 1431-1434.

Momeni, K., Janati, A., Imani, A. \& Khodayari-Zarnaq, R. (2018) Barriers to the development of medical tourism in East Azerbaijan province, Iran: A qualitative study of Tourism Management; 69:307-16. doi: 10.1016/j.tourman.2018.05.007.

Reddy, G.R., York, V.K. \& Brannon, L.A. (2010). Travel for treatment: Students' perspective on medical tourism. International Journal of Tourism Research, 12(5), 510-522.

Smith, R., Álvares, M. M. \& Chanda, R. (2011). Medical tourism: A review of the literature and analysis of role for bi-lateral trade. Health Policy, 103, 276-282.

Teh, I. (2007). Healthcare tourism in Thailand: Pain ahead? Asia Pacific Biotech News, 11(8), 493-497.

Ye, B.H., Qiu, H.Z. \& Yuen, P.P. (2011). Motivations and experiences of Mainland Chinese medical tourists in Hong Kong. Tourism Management, 32(5), 1125-1127.

Yoon, Y. \& Uysal, M. (2005). An examination of the effects of motivation and satisfaction on destination loyalty: a structural model. Tourism Management, 26(1), 45-56.

Yu, J.Y. \& Ko, T.G. (2012). A cross-cultural study of perceptions of medical tourism among Chinese, Japanese and Korean tourists in Korea. Tourism Management, 33(1), 80-88.

*** Korean Institute of Hospitals Management (2009). Retrieved January 10 from http:// www.kams.or.kr/

*** Tourism Review, 66(1/2), 4-15. Henderson, J. C. (2004). Healthcare tourism in Southeast Asia. Tourism review International, 7(3-4), 111-121.

Submitted:

07.12.2019
Revised:

21.04.2020
Accepted and published online 28.04.2020 